\title{
CONSTITUTIONAL SUPPORT OF THE ENTREPRENEURSHIP LEGALITY IN UKRAINE
}

\author{
Serhii Penkov ${ }^{1}$, Maryna Voloshyna²
}

\begin{abstract}
The article is devoted to the analysis of constitutional support of entrepreneurship legality in Ukraine and its functional purpose in the current conditions. The modern state of the constitutional instruments of government support of entrepreneurship in Ukraine is analyzed in its entirety; available accounting modes related to the official registration of natural and legal entities as economic agents as well as the prescription of regulatory requirements for conducting business in Ukraine are characterized. The authors formulate own view of the concept "entrepreneurship legality in Ukraine" taking into account modern development trends in business relations and objective necessity of their regulation through the constitutional means. Scholarly approaches to the definition of the concept "legal support of entrepreneurship" are studied. The paper proves that entrepreneurship faces the challenges, and sometimes it is impossible to solve the problems of local, regional, nationwide and global level, which evolve under the influence of non-market factors, independently. In order to resolve the above problems, it is essential to involve the state and provide conformity of the adopted policy in the business sector. The key impact factors and roadmap for further development of entrepreneurial activity are defined. The paper highlights the blocks of regulatory legal acts. Certain components of the constitutional support, which will have a favorable effect on entrepreneurial activity, are identified. The article generalizes the ways for improvement of the constitutional support of a business activity that further form four specific measures on effective and overall legal support of the entrepreneurial activity.
\end{abstract}

Key words: business activity, government regulation of entrepreneurship, legality, constitutional guarantees, constitutional means, constitutional mode, entrepreneurship, entrepreneurial activity, freedom of enterprise, business entity.

JEL Classification: L31, L32

\section{Problem statement}

Using a set of legal rules consolidated in the Constitution of Ukraine, legislative, regulatory legal acts and bylaws, it is established the conduct standards for business entities in the course of their entrepreneurial activities, and responsibilities for violations of these standards are determined. Furthermore, the role and significance of public administration authorities are in establishing a regime similar to all business entities in order to create an optimal environment for conducting this type of economic activity, controlling compliance with rules and standards as well as legal requirements in the area under consideration. Thus, the constitutional support of entrepreneurship legality in Ukraine means a complex of legal rules consolidated in the Constitution of Ukraine, legislative, statutory and individual acts which set conduct rules of business entities when carrying out economic activities and establish liability for violation of these rules.

Corresponding author:

${ }^{1}$ Dniprovskii University of the Humanities, Ukraine.

E-mail:mpv12@i.ua

${ }^{2}$ Dnipropetrovsk State University of Internal Affairs, Ukraine.

E-mail:mpv12@i.ua
Whereas, the constitutional support of the legality of entrepreneurship in Ukraine, on the one hand, protects business entities in terms of obligatory enforcement of their legal rights and interests and, on the other hand, they are subject to the measures of administrative coercion in case of violation of consumer rights, antitrust, tax, environmental legislation. The content of constitutional support of the entrepreneurship legality involves clear, consecutive and precise exercise of powers by central and local authorities regarding the regulation of legal relations, which arise in the area of enjoyment of the constitutional right to entrepreneurial activity and creation of the system of the state guarantees of support and contribution to entrepreneurial activity. The legal support creates that environment, where an entrepreneur acts, guaranteeing him/her state protection of property rights, equality of rights and freedom of enterprise, free and legal competition, government assistance. 
Both economic researchers and legal scholars have paid much attention to the problems of the study of entrepreneurial activity, clarification of its content and essence, special aspects of the legal regulation of the latter, namely: O.V. Bihniak, Yu.P. Bytiak, V.V. Bohutskyi, T.O. Kolomoiets, A.T. Komziuk, V.K. Kolpakov, O.V. Kuzmenko, A.S. Lastovetskyi, I.D. Pastukh, A.S. Vasyliev, O.P. Podtserkovnyi, V.S. Shcherbyna, N.A. Saniakhmetova, O.M. Vinnyk, V.A. Ustymenko, R.A. Dzhabrailov, V.M. Kamp, V.V. Kovtunets, O.D. Krupchan, Yu.M. Frolov, S.V. Riznyk, P.P. Shliakhtun, Yu.O. Khorkov, et al.

At the same time, a fundamental change in the requirements for the activity of public administration bodies in the updated standards of living of the society and the state necessitates the revision of the existing constitutional means of ensuring legitimate (lawful) entrepreneurial activity in Ukraine. Moreover, problems of the advance of the government regulation mechanism of entrepreneurial activity under the conditions of intensification of the integration process in the country are top targets and require comprehensive research. There is a need in the separation and generalization of the terminology "public administration" regarding the concept of constitutional support of the legality of entrepreneurial activity in Ukraine.

\section{Means of the constitutional support of the legality of entrepreneurial activity in Ukraine}

The legality (legitimacy) of entrepreneurial activity in Ukraine should be comprehended as the legitimization (extension of legal validity) of entrepreneurial activity, which is carried out by duly registered business entities, that is actual procurement of a right to conduct a business by the latter in the manner, which is established relying on the constitutional right of everyone to carry out that kind of economic activity as well as the general principles of economic management defined in Art. 6 of the Economic Code of Ukraine (hereinafter referred to as the EC of Ukraine). The legitimate nature of entrepreneurial activity ensures the protection of life, health and property of each member of society as well the protection of the environment, economic national security of the state. Thus, the legality of entrepreneurial activity directly affects the enhancement of the national economy, the saturation of the domestic market with consumer goods of national production, providing social and property protection of citizens, the conquest of foreign markets, world economic influence, the skilled work of the management apparatus in the area of administrative and legal regulation of the mentioned industry, etc.

Content analysis of Art. 4 of the EC of Ukraine, which defines the groups of relations that are beyond the subject-matter of the statutory regulation of this codified act, makes it possible to establish legal relations under the administrative regime in the business area, in particular, in terms of: the use of resources (material, natural, labor, financial); arrangement of carrying on business activity, including entrepreneurial one (payment of remissions and mandatory payments, protection of economic competition, defense of consumer rights, etc.); compliance with special conditions of carrying out particular types of business activity (licensing and permissive conditions); conducting some transactions. In this context, the fixing of the administrative regime, as a set of legal fundamentals and essential organizational management measures, is executed to ensure the procedure for the exercise of rights and obligations by individuals as well as the operating procedure of state bodies that is consistent with public and private interests in the mentioned sphere of public administration (Hospodarskyi kodeks Ukrainy, 2003). In the course of the abovementioned, we note that it is management functions in different activities (tax, sanitary, environmental etc.) that are formal characteristic for the establishment of administrative regimes.

Public administration aim means the execution of functions clearly defined by the law. These functions may be formulated in the regulatory regime rules or originated from the regime requirements for the functioning of control systems (Artemiev, 2019).

Regarding the legal regime of entrepreneurial activity as a statutory set of rules on the conduct of natural and legal entities as entrepreneurs and the exercise of their rights and responsibilities in the specified area, it is safe to say that this is a functional regime regulating the economic function peculiar to any system of social, including public, administration. This is because its principles are laid in Art. 42 of the Constitution of Ukraine (Konstytutsiia Ukrainy, 1996), and its further consolidation is in the core codified act in the system of economic legislation: the Economic Code of Ukraine which provides government control of entrepreneurial activity, and other legislative and subordinate statutory acts.

When exercising the regulatory influence on the entrepreneurial activity through relevant legal standards, it is defined the legitimate (lawful) development vector of that sort of activity, including precise and comprehensive principles, limits and procedure for its implementation. This, in turn, ensures the use of legal regulation mechanism focused on creating proper conditions for lawful entrepreneurship and effective management of the economy based on the constructive legal means of regulatory, in particular, the administrative influence of the state on business entities activity. Among the legal means, one can name the following: government order, application of standards, limits, scientific and technical, economic, socio-state and regional programs; contracts for works and supplies for state needs; regulation of prices, tariffs, exchange rates, amount of economic sanctions; provision of grants-inaid, compensations, targeted subsidies, credits for the 
stimulation of technology modernization, innovation activity, assimilation of new types of products and services; provision of state property (industrial and non-residential premises, inactive and unfinished objects and structures necessary for business activities); provision of tax, compensation and other benefits, etc.

Certain legislative rules contain legal prescriptions of an administrative nature and, typically, their implementation is impossible without the use of administrative procedures in which, ad hoc, there is a visible specification of the content of a relevant administrative-legal regime in the economic, including business, area. In this context, the regulation of entrepreneurial activity is caught up due to the application of accounting regimes as individual administrative-legal types based on the purposefulness feature which legalize (determine and justify legality and legitimacy) business entities. In other words, they consolidate features of both registration of legal and natural entities and the rulemaking of statutory requirements for the relevant type of business activity. Thus, the obligatory legal means of law enforcement of business activity involve as follows: state registration of business entities; licensing and patenting of certain types of business activities; registration of participants of foreign trade activity; allocation of quotas for the export and import; standardization and certification, protection against unfair competition.

State registration of legal entities, non-governmental organizations that do not have the status of legal entity and natural persons - entrepreneurs - is an official recognition by state averment of the establishment or termination of the activities of a legal entity, a non-governmental organization, which does not have a legal identity, averment of the relevant status of nongovernmental organization, trade union, its agency or association, political party, employers' organizations, associations of employers' organizations and their symbols, evidence of acquisition of the entrepreneur status by a physical entity or its deprivation, changes in the information contained in the United State Register of Legal Entities, Individual Entrepreneurs and Public Organizations about a legal entity and an individual entrepreneur, as well as carrying out other registration actions stipulated by this Law.

To legitimate the carrying out certain types of entrepreneurial procedures, which influence their security, as well as to protect property interests by the state, the legislator requires of a business entity to acquire approvals. Thus, the Law of Ukraine "On Licensing Types of Business Activity" defines the fundamental principles of licensing, types of business activity subject to licensing, the procedure of their licensing, introduces accountability of business entities and licensing authorities for the violation of licensing legislation. According to para. 6 p. 1 of Art. 1 of the above Law, licensing is a means of government regulation of conducting business activities which are subject to licensing, targeted at supporting the implementation of a unified state licensing policy, protecting economic and social interests of the state, society and individual consumers (Pro litsenzuvannia vydiv hospodarskoi diialnosti, 2015). There are particular licensing provisions in Art. 14, 43, 128 of the EC of Ukraine and part 3 of Art. 91 of the Civil Code of Ukraine (hereinafter referred to as the Code).

The juridical literature has a point according to which the licensing of certain types of business activity is considered from different perspectives: as an element of business entities legitimation; as a condition of conducting certain types of business activity; as a bases for the origin of law to carry out types of business activity which are subject to licensing; as an element of the mechanism for the implementation of the constitutional right to entrepreneurial activity; as a means of government regulation of business activity (Vasyliev, 2018). It seems erroneous to separate such aspects as "a bases for the origin of law to carry out types of business activity" and "a condition of conducting certain types of business activity" that are infused with each other because the eligibility to do business is one of the conditions of legal carrying out of that kind of economic activity.

Such direct ways of administrative non-tariff regulation as quota allocation (quantitative restrictions) and patenting that are currently determined to be the methods of government regulation in the economic sector, which are focused on providing a unified state control in the sector and protecting the economic and social interests of the state, society and individual consumers, are related to the licensing. The essence of quota allocation lies in establishing trade turnover by the state that determines the quantity and nomenclature of importable or exportable goods by a certain number or amount for a definite period. In this context, it is appropriate to present the statement of O.V. Havrylchenko, who explains that quota is a quantitative non-tariff restriction on goods' export or import by a fixed number or amount for a specified period. Then, the scholar marks that quotas are the maximum volumes of some goods that can be imported (exported) into the country within a certain period (Havrylchenko, 2013).

In terms of the legislation, the Law of Ukraine "On Foreign Economic Activities" (Pro zovnishnoekonomichnu diialnist, 1991) stipulates application of the above non-tariff methods as effective means regulating foreign economic activity through setting some requirements for economic entities. The EC of Ukraine, in particular, p. 5 of Art. 14, clarifies that the state uses quota allocation fixing a critical volume (quotas) of production or trade where it is required. The procedure for quotas of production and / or circulation (including export and import), as well as quotas 
distribution, is established by the Cabinet of Ministers of Ukraine under the law. At the same time, the Civil Code of Ukraine consolidates provisions on the agreed economic law institutions: buy-sell, procurement and other exchange forms; general and building contracts, cargo carriage (Tsyvilnyi kodeks Ukrainy, 2003).

The authors note that certain types of business activity require a trade patent. Thus, patenting of entrepreneurial activity of business entities may be performed in the areas related to the trade for monetary funds (cash, checks, and use of other payment forms and cash cards in the territory of Ukraine), exchange of cash currency values (including transactions with foreign cash means and payment cards), in the area of gambling business and consumer services, other areas ascertained by the law. An official document that entitles a business entity to carry out the activity, which is subject to patenting, is trade patent - state certificate which confirms the right of the business entity to run certain types of entrepreneurial activity within a fixed timeframe (Kovach, 2017).

Such permissible procedures as certification and standardization, which are primarily intended to secure and protect life, health and property of citizens and the environment from the adverse effects of modern scientific and technological development, dishonest manufacturers, authorized representatives, importers and distributors as business entities, and creating the adequate conditions for bona fide competition call for special attention.

In particular, legal certification fundamentals are defined by the Law of Ukraine "On Standards, Technical Regulations and Conformity Assessment Procedures", which sets legal and organizational principles of conformity of product, quality system, quality control system, environmental management system, human resource management system and focuses on support a unified state technical policy in conformity assessment (Pro tekhnichni rehlamenty ta otsinku vidpovidnosti).

Juridical literature interprets the term "certification" as: the activity of the competent state bodies, institutions, organizations and their officials, which is associated with the issuance and receipt of the relevant certificate by legal or natural entities; as confirmation of compliance of qualitative characteristics of production with specified requirements (standards) or level established by standards (Mamatova, 2018). As proof of the conformity (release of compliance document, which is based on the decision about the fulfillment of specified requirements, is proved after the critical examination) of products, processes, services, system or staff by the third party (a person who is independent of the person providing the conformity assessment object and of the person who is interested in the object as a consumer or user), the Ukrainian legislator defines the term "certification" in Art. 1 of the Law of Ukraine "On Standards, Technical Regulations and Conformity Assessment Procedures”.
However, from the scientific viewpoint, today some scholars consider certification as one of the directions of permitting activities, the essence of which lies in developing and implementing a complex of measures, which are aimed at preventing damage that can be caused to public and state interests, property, personal safety of citizens due to uncontrolled production and sale of products that may be dangerous for the person. It is clear that certification is currently presented in the form of a relevant procedure, which is related to the provision of a permit document for the release, placement into service or introduction on the product market, rendering of services, the determination of the conformity of systems or personnel to certain quality criteria, the statutory requirements fixed in technical regulations, standards, technical specifications or in another way.

Along with certification as a necessary tool for managing the quality and safety of products, processes, services, systems or company staff, standardization is also a major figure which, according to Art. 4 of the Law of Ukraine "On Standards, Technical Regulations and Conformity Assessment Procedures”, focuses on: compliance ofstandardization objects with theirpurpose; diversity management, applicability, compatibility, interchangeability of standardization objects; support of the rational production through the application of designated rules, guidelines and procedures; ensuring health and safety; protection of consumers' rights and interests; work safety; preserving the environment and saving all kinds of resources; elimination of technical barriers to trade and their prevention, support of the development and international product competitiveness (Pro standartyzatsiiu, 2014). In A.M. Chorna's good point, the standards are not intended to permit certain activities, but they are a condition for conducting a business related to manufacturing, processing and other activities that require their application (Chorna, 2017). The above confirms that all business entities shall adhere to the special requirements, which are set out for production and its parameters that may threaten health and life of persons, their property or may not correspond to the accuracy and uniformity of measurements, specifications of manufacture and operation.

The protection of the establishment of trade and other fair customs of competition when conducting business activities in the context of market relations makes the difference among administrative-legal means ensuring lawful entrepreneurial activity. Thus, according to Art. 37 of the EC of Ukraine, actions defined as unfair business practices entail administrative, civil or criminal liability of the perpetrators - economic entities - as provided for by the law. The Law of Ukraine "On Protection against Unfair Competition" interprets the concept of "unfair competition" as "any actions in the competition which contrast with rules, trade or other honest practices in business activities" (Pro zakhyst vid nedobrosovisnoi 
konkurentsii, 1996). P. 1 of Art. 32 of the EC of Ukraine also contains the above definition, and it is more detailed in p. 2 of the same article as follows: "the unlawful use of the goodwill of a business entity, obstructing business entities in the competitive process and the achievement of unfair advantages in competition, the improper collection, disclosure and use of trade secrets, as well as other competition actions that are contrary to rules, trade and other fair customs in business”.

\section{Model of the constitutional support of the entrepreneurship legality in Ukraine}

The content of legal support of entrepreneurial activity involves a clear, consecutive and precise exercise of powers by central and local authorities regarding the regulation of legal relations which arise in the area of enjoyment of the constitutional right to entrepreneurship and creation of the system of the state guarantees of support and contribution to business activities. The legal support creates that environment, where an entrepreneur acts, guaranteeing him/her state protection of property rights, equality of rights and freedom of enterprise, free and legal competition, government support.

The legal support of entrepreneurship should be a legal strategy of the state, public administration bodies and business entities, which includes the rules, ways and methods of business relations control; consolidation of business law enforcement in the economy; fulfillment of state instructions, treaties conditions, national and regional programs of socio-economic development. Laws and other statutory acts ensure the realization of legal regulation and aim to create the conditions for legal managing and effective management of the economy through meaningful legal means. The effectiveness of legal support depends on the degree of perfection and effectiveness of economic legislation (Shebanits, Rudenko, 2016). At the same time, there are the following negative factors of the legislation: uncertainty of priority of legislative acts on business activity regulation; complexity and extensionality of the regulatory framework; constant changes and amendments to the laws; instability and internal contradictions of legislative acts and their individual norms regarding the regulation of business relations; disproportion in the ratio of laws and subordinate acts, their declamatory nature; the absence of implementation mechanisms in many laws; inappreciation of issues related to the realization of human and civil rights and freedoms guaranteed by the international conventions, which were signed and ratified by Ukraine.

Legal support is intermediated by two directions of entrepreneurial activity control: regulation of the procedure for implementing the right to entrepreneurship guaranteeing its stability and determining the legal status of economic entities, as well as defining the goals, organizational and legal means, methods and practices of influence of the state on ordering relations in the context of conducting business activity (Ishchuk, 2018).

Today, Ukraine is at the stage of formation and development of a stable market economy and, therefore, the state faces the task of creating both economic and social preconditions that would allow the effective development of entrepreneurship. Studying the evolvement of economic relations, one may state that legislation has ceased to be the groundwork of the legal regulation and does not guarantee the exercise of state, branch and regional programs of the socio-economic development.

Effective legal support of the entrepreneurial activity should be considered as the availability of the expected result from the introduction of legislation in the specified economic realm in order to achieve the specified goal through implementing the legal means defined by law. In reliance on the above definition, content of the effectiveness of laws on legal support of entrepreneurship is the realization of a complex of professionally elaborated legal means for accomplishing the following goals: enhancement of the national economy, the saturation of the domestic market with consumer goods of national production, providing social protection of citizens, the conquest of foreign markets, world economic influence, the skilled work of the management apparatus in the area of state control of the mentioned industry.

For the advancement of entrepreneurship in Ukraine, it is necessary to develop an effective legal framework regulating the activity of business entities. The state should elaborate a flexible system of business taxation to create favorable conditions for their stable profit (Bavyko, 2017). The state support of entrepreneurs should include their legal protection, the creation of relevant information and advisory base, contribution to the investments attraction in the development of domestic entrepreneurship.

The Ukrainian business legislation consists of the laws of Ukraine and resolutions of the Cabinet of Ministers regulating business activity, statutory acts of ministries and departments, local self-government bodies, including those state bodies, which carry out entrepreneurship regulation, control and supervise it. Business legislation of Ukraine can be divided into three blocks of statutory acts: the Constitution of Ukraine, according to Art. 42 every citizen has the right to legal entrepreneurial activity (the right is based on the freedom of entrepreneurship which involves doing a legal business by a person at own discretion and risk to earn a profit; a block of special statutory acts regulating exclusively entrepreneurial activity: Laws of Ukraine "On Business Associations", "On Joint Stock Companies”, "On Farming Enterprise”, "On State Registration of Legal Entities and Individual 
Entrepreneurs”, “On Development and State Support of Small and Medium-sized Enterprise in Ukraine" and others; regulatory legal acts which are comprised of individual regulatory provisions or their set controlling entrepreneurship: the EC of Ukraine, the Civil Code of Ukraine, the Tax Code of Ukraine, Laws of Ukraine "On Licensing of Certain Types of Business Activities", "On Consumer Rights Protection”, "On Protection of Economic Competition”, "On Protection Against Unfair Competition", "On the Permit System in the Field of Economic Activity”, “On Restoring a Debtor's Solvency or Recognizing It as Bankrupt” and others.

Major deficiencies in the legal support of entrepreneurship in Ukraine are as follows: equivocation, instability and controversial nature of the current legal framework of entrepreneurship; virtually non-functional character of many legal acts, very low operational discipline regarding regulatory documents; the occurrence of many fuzzy legislative rules that can be subject to any interpretation if desired; inconsistency of legal restrictions and requirements contained in the individual legal acts.

The promotion of entrepreneurship in Ukraine is identified as one of the principal directions of market reforms and is an important task of the state regulatory policy. Entrepreneurship and its influence have a great impact on the socio-economic transformations. First of all, it includes additional revenues to the state budget, new jobs, expansion of production of goods and services for both industrial and household purposes, introduction of know-how and other achievements of scientific and technological progress, improvement of welfare of the population, etc.

The effective functioning of the entrepreneurial activity is a quite long process which should be performed, taking into account the economic and legal situation in the country, current problems which destabilize enterprises operation. Analyzing the domestic legal framework of entrepreneurship, one can argue that, on the one hand, the state has a significant influence on it and, on the other hand, it is insufficient. In view of the above, present conditions require the development and implementation of effective mechanisms of state regulation that would stimulate the promotion of the entrepreneurial activity (Mozhaikina, 2017). The following ways may improve the state regulation of entrepreneurship expansion in Ukraine: upgrading of current legal acts controlling business activity to eliminate internal legal contradictions and abolishing provisions that hinder entrepreneurial development; further implementation of the state regulatory policy in the economic activity for the creation of a favorable business environment; intensification of financialcredit and investment support of entrepreneurship; contribution to the creation of business development infrastructure; improvement of the tax system, which would ensure a sufficient amount of payments to the budgets of all levels, efficient performance of the domestic economy, fair approach to taxation of all categories of taxpayers; formation of the proper legal environment for the development of innovative and scientific and technical activities, enhancement of the entrepreneur's motivation for high-yield and highquality activities through advancing the system of economic incentives by amending the tax and customs legislation.

The central tasks of the state are all-round stimulation of activity in the area of production, creation of favorable conditions for entrepreneurship, as well as ensuring employment of the population, social care of the most vulnerable strata of society, that is, to provide citizens with a decent standard of living. For this very reason, the state's role in economic public life is currently increasing. This is manifested in the development of a system of regulatory acts intended to control the market, business, customs rules, banking line, prices and salaries, social protection of the population. Therefore, it is legal regulation, which plays a major role in business control because entrepreneurship is a scope of engagement the state and market (Baklan, 2011). In general terms, the improvement of legal support of entrepreneurial activity should be performed by the following areas:

- the need to establish encouragement through agitation means, persuasion of public opinion since prosperous entrepreneurs are the basis of the material wealth of all other strata of the population;

- the need to ensure the functioning of a market economy by providing the legal framework and social atmosphere, which contribute to the successful development of entrepreneurial activity and create conditions for entrepreneurs integration into the overall area of social responsibility and support of the stability of economic reforms and the implementation of programs of socio-economic development;

- reforming of regulatory relations between the state and business entities in order to overcome opposition to the course of regulatory and administrative reform and inertia of public administration bodies which are endowed with regulatory policy responsibilities.

Improvement of the legal support needs updating of: provisions which determine the legal status of business entities in the course of realization of their economic competence and optimization of state regulation; the essence, content and effectiveness of laws; determination and effectiveness of administrative and commercial liability; the legal mechanism for enforcement and protection of economic and social rights and interests of entrepreneurs; legal bases of administrative activity of public administration; legal means to eradicate corruption in the economic and public sectors; the procedure of balancing state and public interests with interests of business entities (public with private); organization of measures for adaptation of the national business legislation to the European legislation; 
fundamental provisions on the legal regime of property (adoption of the law on property); economic and legal mechanism of legalization of shadow capital, shadow activity and shadow economy.

Analyzing the effectiveness of legal support of entrepreneurship, the following measures are proposed: - intensification of the involvement of the business community in a constructive dialogue with public administration bodies regarding decision-making at the state and local levels. Civil servants and officials of local government bodies should substantiate the need of taking arbitrary decisions in the open. Laws shall have constructive and character and creative nature, be a viable mechanism of the state protection, easily understood for business leaders;

- working out draft laws relying on a competent and efficient basis, taking into account their economic feasibility and financial solvency, therefore, the initiation of draft bills should be carried out by experts who have the relevant knowledge and experience in the legal regulation of specific areas of economic activity. Parliament's professionalism is determined by the quality of the content, the productivity and implementing rules. Justification of the expected impact of each draft on the interests of entrepreneurs, the population (consumers) and the state should be a mandatory condition;

- purification of the economic legislation from unnecessary harmful regulations and bylaws which sometimes, as a funfair mirror, which distort the essence of the law because the executive bodies correct and interpret the essence of the law, replace its main provisions with corporate content transforming state interest in favor of the branch. Bylaws become an obstacle to reforming any sector of economy penetrating to the depths of the essence of the law, distorting and twisting its content. Bylaws are necessary as a control means which renders the ways of putting a law into execution. It is untenable that a government decree or an order of a ministry or other central executive body determine the conditions for the development of a particular industry. Such a government act should be economically feasible, financially backed and efficient. Working out its draft, it is important to avoid contradictions, inconsistences and doubling of existing statutory provisions, to balance state and sectoral interests and to control its implementing at the stage of acts execution.
- establishing effective parliamentary consideration under full compliance with the legislative requirements for regulatory activity by the officials central and local authorities (in order to prevent the adoption of economically unfeasible and ineffective regulatory acts, to reduce the state interference in the activity of business entities and to eliminate the obstacles to the development of business activity). It is essential to amend the Code of Ukraine on Administrative Offenses and the Law of Ukraine "On the Fundamental Principles of State Regulatory Policy in the Economic Activity" in terms of specification of the administrative responsibility of officials in the area of state regulatory policy.

\section{Conclusions and further researches directions}

Consequently, from the perspective of public law, in relation to business entities, public administration authorities, on the one hand, undertake and must secure and guarantee legal rights and interests of business entities; protect the inviolability of property and ensure the property rights of the entrepreneur; guarantee equality of their rights to freedom of business activity as well as equal opportunities for access to material-technical, financial, human, information, natural and other resources; protect consumers from the manifestations of unfair competition and monopoly in all business areas, etc. On the other hand, the control of entrepreneurial activity is necessary that the state represented by authorized bodies, officials can monitor those business areas which, first, affect safety provisions, and, second, for the protection of property interests by the state. If business entities violate administrative, tax, environmental legislation, authorized state actors have a right to apply measures of administrative enforcement to them. There is a special focus on the fact that the legislator directly within the basic law (Arts. 42, 78, $120,123,127,141,146$ of the Constitution of Ukraine), codes, and laws of Ukraine, other regulatory legal acts, places limitation of a right to entrepreneurship. However, from the standpoint of private law, public administration bodies are not entitled to interfere with the activity of business entities, which is manifested in various forms of their protection and creation of favorable conditions for them to carry out entrepreneurial activities.

\section{References:}

Artemiev, O. S. (2019). Uzahalnennia klasyfikatsii ta teoretychnykh pidkhodiv do vyznachennia [Generalization of the classification and theoretical approaches to the definition of the term "public administration mechanism"]. Teoriia ta praktyka derzhavnoho upravlinnia i mistsevoho samovriaduvannia, no. 1. Retrieved from: http://nbuv.gov.ua/ UJRN/Ttpdu_2019_1_3

Bavyko, O. Ye. (2017). Strukturno-funktsionalna model pravovoho rehuliuvannia pidpryiemnytskoi diialnosti v Ukraini [Structural-functional model of the legal regulation of entrepreneurship in Ukraine]. Visnyk Donetskoho natsionalnoho universytetu ekonomiky i torhivli im. Mykhaila Tuhan-Baranovskoho. Seriia: Ekonomichni nauky, no. 2, pp. 5-13.

Baklan, O. (2011). Zabezpechennia bezpeky pidpryiemnytskoi diialnosti: informatsiia, zmist, pravova kharakterystyka [Organisation of entrepreneurship safety: information, content, legal characteristics]. Pravova informatyka, no. 1, pp. 54-58. 
Vasyliev, V. M. (2018). Administratyvno-pravove zabezpechennia rezhymu zakonnosti pidpryiemnytskoi diialnosti v Ukraini [Administrative support of the legality of entrepreneurship in Ukraine]. Pravo $i$ Bezpeka, no. 4, pp. 36-42. Havrylchenko, O. V. (2013). Pravove rehuliuvannia pidpryiemnytskoi diialnosti v Ukraini [Legal regulation of entrepreneurship in Ukraine]. Visnyk ekonomiky transportu i promyslovosti, vol. 41, pp. 275-280.

Verkhovna Rada of Ukraine (2003). Hospodarskyi kodeks Ukrainy : Zakon Ukrainy vid 16 sichnia 2003 r. № 436-IV [The Commercial Code of Ukraine: the Law of Ukraine dated January 16, 2003, No 436-IV]. Retrieved from: https://zakon.rada.gov.ua/go/436-15

Ishchuk, S. I. (2018). Okremi konstytutsiino-pravovi zasady funktsionuvannia hromadianskoho suspilstva v Ukraini: svoboda pidpryiemnytskoi diialnosti [Individual constitutional-legal fundamentals of the functioning of civil society in Ukraine: freedom of entrepreneurship]. ScienceRise. Juridical Science, no. 1, pp. 11-17.

Kovach, A. V. (2017). Pravovi umovy isnuvannia i rozvytku pidpryiemnytskoi diialnosti v systemi prav liudyny [Legal conditions of the existence and development of entrepreneurship in the system of human rights]. Derzhavne budivnytstvo ta mistseve samovriaduvannia, vol. 33, pp. 162-170.

Verkovna Rada of Ukraine (1996). Konstytutsiia Ukrainy vid 28 chervnia 1996 r. № 254k/96-VR [The Constitution of Ukraine dated June 28, 1996, No 254к/96-BP]. Retrieved from: http://www.zakon.rada.gov.ua/go/254к/96-вp Mamatova, L. Sh. (2018). Pravove zabezpechennia pidpryiemnytskoi diialnosti v Ukraini [Legal support of entrepreneurship in Ukraine]. Visnyk Pryazovskoho derzhavnoho tekhnichnoho universytetu. Seriia: Ekonomichni nauky, vol. 35, pp. 33-40.

Mozhaikina, O. S. (2017). Pravove rehuliuvannia orendnykh vidnosyn pid chas zdiisnennia pidpryiemnytskoi diialnosti [Legal regulation of lease relations when conducting entrepreneurial activities]. Pravo $i$ suspilstvo, no. 1(2), pp. 95. Science Rise. Juridical Science 98.

Verkhovna Rada of Ukraine (1996). Pro zakhyst vid nedobrosovisnoi konkurentsii : Zakon Ukrainy vid 7 lypnia $1996 \mathrm{r}$. № 236/96-VR [On protection from unfair competition: the Law of Ukraine dated June 7, 1996, No 236/96-BP]. Retrieved from: https://www.zakon.rada.gov.ua/go/236/96-sp

Verkhovna Rada of Ukraine (1991). Pro zovnishnoekonomichnu diialnist: Zakon Ukrainy vid 16 kvitnia $1991 \mathrm{r}$. № 959-XII. [On International Economic Activity: the Law of Ukraine dated April, 16, 1991, No № 959-XII]. Retrieved from: https://zakon.rada.gov.ua/laws/show

Verkhovna Rada of Ukraine (2015). Pro litsenzuvannia vydiv hospodarskoi diialnosti : Zakon Ukrainy vid 2 bereznia 2015 r. № 222-VIII [On Licensing Types of Business Activity: the Law of Ukraine dated March 2, 2015, No 222-VIII]. Retrieved from: https://www.zakon.rada.gov.ua

Verkhovna Rada of Ukraine (2014). Pro standartyzatsiiu : Zakon Ukrainy vid 5 chervnia 2014 r. № 1315-VII [On Standardization: the Law of Ukraine dated June 5, 2014, No 1315-VII]. Retrieved from: http://www.zakon.rada.gov.ua/ go/1315-18

Verkhovna Rada of Ukraine (2015). Pro tekhnichni rehlamenty ta otsinku vidpovidnosti : Zakon Ukrainy vid 15 sichnia 2015 r. № 124-VIII [On Technical Regulations and Conformity Assessment: the Law of Ukraine dated January 15, 2015, No 124-VIII]. Retrieved from: https://zakon.rada.gov.ua/laws/show

Chorna, A. M. (2017). Rozmezhuvannia pravovidnosyn, yaki vynykaiut z pytan zabezpechennia prav subiektiv pidpryiemnytskoi diialnosti u sferi opodatkuvannia [Differentiation of legal relations which arise from the issues of enforcement of rights of business entities in taxation]. Visnyk Chernivetskoho fakultetu Natsionalnoho universytetu «Odeska yurydychna akademiia», vol. 2, pp. 130-142.

Verkhovna Rada of Ukraine (2003). Tsyvilnyi kodeks Ukrainy: Zakon Ukrainy vid 16 sichnia 2003 r. [The Civil Code of Ukraine: the Law of Ukraine dated January 16, 2003]. Retrieved from: http://www.zakon.rada.gov.ua/ go/435-15

Shebanits, F. F., \& Rudenko, O. V. (2016). Deiaki aspekty suchasnoho stanu pravovoho rehuliuvannia pidpryiemnytskoi diialnosti u svitli realizatsii stratehii staloho rozvytku «Ukraina - 2020» [Some aspects of the modern state of legal regulation of entrepreneurship in the light of realization of the sustainable development strategy "Ukraine - 2020"]. Visnyk Mariupolskoho derzhavnoho universytetu. Seriia : Pravo, vol. 12, pp. 130-136. 